\title{
El lugar de la revuelta: \\ pulperías e insurgencia en Venezuela (1750-1850)
}

\author{
NELLER RAMÓN OCHOA HERNÁNDEZ Universidad Simón Bolívar, Venezuela \\ ORCID 0000-0001-9746-0297 \\ nellerochoa@gmail.com
}

\section{Resumen}

Las pulperías venezolanas fueron espacios que reunieron una gran diversidad de alimentos, formas, asistentes e ideas, muchas de ellas contrarias al disciplinamiento que estaba forjando la crisis de la sociedad colonial. Al ser un espacio que se sitúa «entre», donde afloran las tácticas de los desposeídos, podemos abordar los síntomas de una sociabilidad conflictiva que estaba redefiniendo conceptos «modernos» a la luz de estos «tugurios de mala vida», donde, según las ordenanzas, solo debían convivir una caterva de vagos y bandoleros. Quizá no el lugar de las «revoluciones orgánicas», pero sí el de las revueltas, intensas y fugaces.

Palabras clave: pulperías / vagancias / sociabilidad / revuelta / control social

\section{The place of the revolt: pulperias and insurgency in Venezuela (1750-1850)}

Abstract

The Venezuelan pulperías were spaces that gathered a great diversity of foods, forms, assistants and ideas, many of them contrary to the discipline that was forging the crisis of the colonial society. Being a space that is «in between", where the tactics of the dispossessed emerge, we can address the symptoms of a conflictive sociability, which was redefining «modern» concepts in light of these «slums of bad life», where, according to the ordinances should only coexist a bunch of vagrants and bandits. Maybe not the place of the «organic revolutions», but the one of the revolts, intense and fleeting.

Key words: pulperías / vagrancy / sociability / revolt / social control

Recibido: 11/6/2020. Aceptado: 20/9/2020

Para citar este artículo: Ochoa Hernández, N.R. (2020). El lugar de la revuelta: pulperías e insurgencia en Venezuela (1750-1850). El taco en la brea, 12 (junio-noviembre). Santa Fe, Argentina: UNL. eooog DOI: 10.14409/tb.v1i12.9686 
«El vicio predominante de este pueblo es la borrachera» (Martí:289); «La borrachera proviene de haver en este mismo pueblo quatro guaraperías (...) donde se vende guarapo fuerte de día y de noche, y lo beven hombres, mujeres, indios y los que no son indios» (297); «El vicio predominante es acá la borrachera por la bevida del guarapo, que se vende (...) en una casa de pulpería» (305-306)... Estas sentencias engrosan uno de los libros personales del Obispo Mariano Martí; anotaciones realizadas en el marco de su amplia y dilatada visita pastoral a la Diócesis de Caracas entre 1771 y 1784. El informe, que buscaba ordenar, clasificar y diagnosticar a una población diversa, solo nos ofrece trazas del «mal» que se había enseñoreado sobre estas tierras. Aunque Martí proporciona datos demográficos útiles para la iglesia y autoridades civiles, ante la incómoda proliferación de gentes varias solo le queda expresar: «Acá viven estos indios mezclados con españoles, esto es, blancos, negros, sambos, etc.» (402). Tal vez hubiese querido dibujar una relación más exacta sobre estos pueblos, pues dicha información serviría para acrecentar el control social, económico y espiritual, pero los incontables bemoles presentes en su cotidianidad, rebasan su comprensión y le incomodan, haciéndole plasmar breves y discontinuas líneas; restos de una sociabilidad prohibida, donde la pulpería funge como el templo en el que se juntaban todas estas desviaciones.

Para Robert Semple, viajero inglés que visitó Caracas a comienzos del siglo XIX, se trataba de un establecimiento que es «al mismo tiempo, tienda, posada y cortijo en el grado en que pueden serlo según el estado social de la provincia» (34). Sin embargo, fijar la función de la pulpería, así como la calidad y cantidad de sus asistentes es y ha sido una perenne interrogante para autoridades e investigadores. Por ello, en 1823 el ingeniero inglés John Hankshaw expresa, sin más, que la pulpería combinaba las actividades de un clásico almacén y las de una taberna, «especie de mezcla de Gasthof alemana y de tienda ambulante inglesa, no formada» (102), frase que extrañamente coincide con una del citado Martí, cuando hacia 1783 en la locación de Nirgua encontró una casa donde se llevaban a cabo variadas y contradictorias actividades, ante lo que no pudo sino exclamar: «Hay una como pulpería» (322). Este mismo «como» lleno de dudas puede encontrarse también en algunos libros parroquiales, donde algunos pardos se registraban como blancos y viceversa. Por ello:

La proliferación de los híbridos — las castas - con las connotaciones simbólicas y normativas que conllevan (ilegitimidad, deslealtad, vicio, lujuria, metáforas animales) se refleja en un vocabulario que alude a una pigmentación indeterminada, ni negra ni blanca, sino «abigarrada», es decir «de varios colores mal combinados», lo heterogéneo, «lo que es sin concierto». (Bernand:24)

Lo abigarrado, esa apretada síntesis socioeconómica que en un comienzo sirvió de pretexto para clasificar lo desconocido, 'luego se transformó en un gran problema. Hacia 1780, abigarrar era poner a una cosa varios colores sin unión ni orden, ${ }^{2}$ y tanto la sociedad venezolana como las pulperías ofrecían un panorama de saturación. Por ello, las escenas allí desarrolladas se asemejan más a destellos de luz que a libretos ordenados, ya que: «Una sociedad muy abigarrada no tenía por qué tener formas muy definidas de vida» (Romero:139). Para 1849, el término no había perdido vigencia, eso si atendemos las palabras del viajero alemán Karl Appun: «El público de tales pulperías es muy abigarrado y consiste sólo de trigueños, negros y gente de color, principalmente de la clase de los sirvientes o, almas sedientas, entre las cuales los amigos de las bebidas alcohólicas desempeñan el rol más importante» (41). 
Una descripción de Arturo Úslar Pietri en sus Las lanzas coloradas... (1988) puede ilustrar el clima antes descrito. La pulpería estaba llena, el vocerío era ensordecedor; sin embargo, podían entenderse. De las otras mesas no llegaba todo, tal vez frases incompletas que servían para validar o rechazar la conversa, pero: «Una vez instalados comenzaron a observar a los individuos que los rodeaban. No había negros puros. Casi todos eran mulatos (...). La mayoría llevaba, desnudo bajo el brazo, el machete que les servía para las faenas del campo» (79-80). Igualmente señala la confluencia de olores y sabores contrapuestos, donde se colaban la carne frita, las caraotas, las arepas y la jarra de guarapo de piña. Apelar a lo ambiguo no parece cónsono con una reconstrucción histórica «tal como fue»; pero la pulpería no deja más opciones, ya que la misma interpela constantemente a los basamentos de su época y al discurso historiográfico, quizá porque «la ambigüedad es la manifestación alegórica de la dialéctica» (Buck-Morss:30). Lo mismo podría decirse del fundador del pueblo de San Gerónimo de Guayabal hacia 1780. Según Alexander Humboldt, este hombre «no había titubeado en establecer para su provecho una pulpería, es decir, en vender en la iglesia misma bananos y guarapo» (Humboldt:271; énfasis mío).

En este clima repleto de amenazas y de tentaciones para una población que debía ser «obediente», las pulperías, aunque efectivas instancias de aprovisionamiento, fueron enfocadas como anomalía, una que partía de la multitud de los incorregibles atrapados en los «aparatos de rectificación» (Foucault, 2007:300). Según el mismo Foucault, lo monstruoso, desde la Edad Media hace referencia a un temor: la mezcla. Entre 1750 y 1850, observamos una sociedad que parte del miedo a las «castas», atraviesa la «Pardocracia» bolivariana y culmina con el pavor hacia los zambos y mulatos que azuzaron Antonio Leocadio Guzmán y Ezequiel Zamora. Acontecimientos que ponían en duda un andamiaje social endeble, remendado por las Reformas Borbónicas de mediados del siglo XVIII y destrozado con la guerra independentista y las posteriores leyes usurarias-represivas que profundizaron las diferencias durante la República, todo un conflicto si consideramos que uno «de los problemas culturales de los saltos modernizadores es qué hacer con el pasado y con la guerra anterior, con sus discursos y sus tonos» (Ludmer, 1995:5).

\section{Lo popular}

Si en las pulperías confluía el pueblo, entonces su naturaleza tuvo que adaptarse a las muchas particularidades de este huésped. Y es que "el pueblo" no existe. Lo que existe son figuras diversas, incluso antagónicas del pueblo, figuras construidas privilegiando ciertas formas de reunión, ciertos rasgos distintivos, ciertas capacidades o incapacidades» (Rancière, 2014:120-121). Aun cuando las definiciones estén allí para hacer referencia a un criterio demográfico, político o netamente económico, el pueblo que hablaba desde las pulperías lo hacía desde la falta, y pese a ser considerado como parte de la misma «chusma», su drama «era la imposibilidad práctica de lograr todos esos objetivos que podían parecer como contradictorios» (Rey:154). Pero esta duda, es decir, la incapacidad de representar al pueblo «tal como fue», impide reflejar un elemento de mucha importancia en su conformación como lo es la potencia, desde la que «los pueblos afirman a la vez lo que les falta y lo que desean» (Didi-Huberman 2014:99).

¿Es popular una pulpería? A primera vista la pregunta se hace impertinente, más cuando se repite hasta la saciedad, que a estos recintos asistían esclavos, morenos libres, pardos, indios, zambos y blancos de ambos sexos, bautizados sin más como vagos y malentretenidos. Todavía en 1849 el alemán Karl Appun señala: «La pulpería donde estaba, rebosaba continuamente de 
gente y de viajeros de todas clases»; es decir, «caballeros, señoritas, arrieros, peones e incluso el vagabundo andrajoso» (Appun:236). Pero en algunos casos, esta definición se tomaba como errónea, pues «El "pueblo" de que se hablaba (...) era concreto: eran los cabildos, las corporaciones, las juntas, en fin, eran los cuerpos intermedios de la sociedad» (Annino:164). Si atendemos a este llamado, podríamos decir que ese "pueblo» también estuvo presente en la pulpería, tal y como expuso el alcalde Joseph de las Llamozas en 1815. Para él, aparte de las embriagueces y quimeras que allí se daban, lo más preocupante era la presencia de los «hijos de familia».3

Ese «pueblo ciudadano» de principios del siglo XIX que se debatía entre las enseñanzas modernas y su accidentada recepción en las calles caraqueñas, también entraba a estos «recintos del mal». En medio de una tensa noche de noviembre de 1808 , cuando los rumores juntistas se encontraban en su máxima expresión, Miguel José Sanz, quien se había mantenido expectante, es sorprendido por José Tovar y Miguel Ustáriz de camino hacia la plaza San Jacinto. Querían algunos consejos legales y políticos en la redacción del documento que se entregaría a las autoridades, y para ello, Tovar le pidió a Sanz que pasaran a la casa de otro conjurado: José Félix Ribas. El abogado se negó, tal vez a sabiendas de que ese lugar estaba siendo vigilado; por ello entraron a una bodega cercana donde según declaraciones de Sanz, les enmendó algunas palabras para «desembarazarse». ${ }^{4}$

Un documento que pretendía definir los destinos de la antigua colonia española había sido corregido desde el ambiente bullicioso de una bodega, ante la indiferencia, o los ojos inquisidores de comerciantes y clientes, quienes seguramente tomaban sus precauciones al momento de recibir a estos mantuanos, tan diversas como adularlos, hasta el maldecirles en silencio y cuchichear sobre el seguro fracaso de la iniciativa patricia. Pero también la estrategia de Sanz es digna de comentar. Si los metió en una bodega, fue porque pensó que sus comentarios y acciones serían más «privadas» allí, beneficio que no le ofrecería la calle o incluso la casa de Ribas. O tal vez Sanz se había introducido en un recinto donde la gente no opinaba sino rumoraba, lo que hacía daño pero no cambiaba las cosas del todo, pues según este personaje: «[E]n un sentido lato más propio y riguroso la voz Pueblo solo comprende a los que teniendo propiedades y residencia se interesan por ellas en la prosperidad de la cosa pública, pues los que nada tienen solo desean variaciones ó innovaciones de que puedan sacar algún partido favorable». ${ }^{5}$

Esta concepción de "pueblo-ciudadano» inspiró a los constituyentes de 1811 a redactar una Constitución censitaria que también levantó las más enconadas reacciones entre quienes no tenían el derecho ni la facultad de opinar. El concepto de "pueblo» se movía entre fronteras movibles, pues aunque esta versión ciudadana del mismo se impuso en casi todas las constituciones del siglo XIX, el término lleva consigo una polisemia que lo ha acompañado hasta la actualidad. ${ }^{6}$ Pero «el pueblo», invitado especial a todas las sesiones y discursos de esta época, se convirtió en una cera blanda presta a ser moldeada. El verdadero pueblo debía ser «leal, noble, justo, desinteresado, aguerrido, glorioso, arrojado, etc.» (Serrano:168); por ello, la jornada del 19 de abril de 1810 la protagonizó el «bravo pueblo» caraqueño, principal inspiración para confeccionar la canción patriótica que luego se convertiría en el Himno Nacional de Venezuela. Sin embargo, así como entraba al cielo, podía ser desterrado al infierno de un solo envión. Por lo tanto, observamos cómo ese «bravo pueblo» se convierte rápidamente en «hordas infernales». No se equivoca Rafael María Baralt cuando lo define así: «El pueblo, ese ente que cada partido define a su manera, que todos creen tener a su disposición, que todos llaman en el momento de peligro, que todos olvidan después de la victoria» (61). 
La confluencia de varios «pueblos» en la pulpería contradice algunas nociones sobre lo «popular». Cuando desde la nostalgia se recrea un lugar donde confluían todas las virtudes del pueblo, se olvida que "La "cultura popular" supone una operación que no se confiesa. Ha sido necesario censurarla para poder estudiarla» (De Certeau, 1994:30). Una buena recomendación, si se considera que descalificar a priori estos espacios tampoco permite indagar en los matices de las peleas, discursos y negociaciones que allí se llevaron a cabo. Justo cuando la pulpería ya no reviste el peligro del bandolero, de la mezcla; cuando el «desorden» de sus productos es sustituido por anaqueles ordenados de las tiendas departamentales, en ese momento lloran la extinción del «centro de la vida modesta, apacible e independiente de nuestros pueblos» (Castellanos:275-276).

Ya no estaban, habían desaparecido o cambiado de lugar, tal como lo testimonian las denuncias de las autoridades caraqueñas por la sociabilidad del barrio «El Silencio» a comienzos del siglo XX. La modernización de Caracas dejaba huellas, y hacia la mitad de este siglo, Mariano Picón Salas observa con desprecio cómo el pueblo asistía «mudo y desengañado a esta bacanal de los ricos», salvo «en las pulperías del barrio de Catia» (140). Pero en este imaginario, la pulpería también fue sinónimo de abundancia, aun cuando en su interior pulularan jornaleros malnutridos y una muchachada ávida de ñapas, así «La pulpería de hace cuarenta años testimoniaba una autarquía alimenticia» (Castellanos:279). Para Michel de Certeau, detrás de las continuas alabanzas a la inocencia y frescura de la cultura popular, se esconden los intentos de asesinarla: «siempre será necesario un muerto para que tenga la palabra» (De Certeau, 1994:10).

Con el tiempo se inventa una nueva pulpería. Una desprovista de conflictos sociales y del constante desprecio sufrido por dueños y asistentes. Pero este ejercicio quiere evocar «el pasado» de manera exacta y no la «impureza esencial» (Didi-Huberman, 2011:60) propia de la memoria. Dosificar los despojos inconformes de un siglo lleno de amenazas y contradicciones para construir un relato homogéneo y ascendente fue un gran reto para los nacientes estados latinoamericanos, ya que la independencia, hito glorioso e inicial de esa narrativa, también llevó consigo el germen de la desigualdad y el resentimiento, ambas peligrosas para la tan ansiada unidad nacional. Con esta pulpería, atiborrada de vicios y peligros que luego deviene paraíso perdido, ocurre algo parecido que con el gaucho argentino, quizá ejemplificado en el Martín Fierro de José Hernández. Un personaje que en la «ida» se caracteriza por su irreverencia y manejo de los códigos populares tan chocantes al orden establecido, y que a la «vuelta» recomienda insertarse lo más pronto al Estado liberal. En este corolario, Hernández aglutina una gran cantidad de registros — propios de la cultura gaucha - y los rehace en una especie de tratado de redención para con el Estado, ${ }^{7}$ manejo que le sirve para impulsar al gaucho como símbolo nacional argentino, y que le permite introducirse en un problema de gran importancia: «el uso letrado de la cultura popular» (Ludmer, 2000:17).

En 1847, Cecilio Acosta, importante ensayista y político venezolano, trata de asir algo que se desborda constantemente. Para Acosta los síntomas son inequívocos. Partidos populares, líderes populares, canciones populares. Tanta presencia de pueblo parece sospechosa; si todos son el pueblo ¿quién es el pueblo? Para el tratadista, ese colectivo es la «reunión de todos los buenos» compuesto por los «leales militares, de los industriales y jornaleros contraídos; (...) el clero que predica la moral, los propietarios que contribuyen a afianzarla, los que se ocupan en menesteres útiles, que dan ejemplo de ella», ${ }^{8}$ y en él no debería entrar la hez inmunda de bulleros, rufianes y bandidos que asistían a tabernas y garitos. Ahora bien, si consideramos algunas narraciones del siglo XIX, podríamos concluir que la pulpería era taberna y casa de juego a la vez, condición que 
la hacía peor, al igual que sus visitantes. En pocas palabras, a las pulperías no asistía el pueblo sino sus desechos, lo cual reviste una gran trascendencia, dado que a partir de ellos se puede «desmontar la historia y montar las discontinuidades, los tiempos heterogéneos que congregan supervivencias, anacronismos, síntomas, latencias» (Didi-Huberman, 2011:21-21).

El encapsulamiento del término "popular», situado en un esquema fatalista de «alta» $\mathrm{y}$ «baja» cultura, donde los extremos no se tocan y solo existe una ciega imitación de arriba hacia abajo, ${ }^{9}$ impide observar conceptos como los de mediación, cuando la cultura popular es «un campo de batalla donde no se obtienen victorias definitivas, pero donde siempre hay posiciones (...) que se conquistan y se pierden» (Hall:5). En las pulperías, tanto asistentes como empleados, dueños y demás autoridades, se entremezclaron en una serie de relaciones que reflejaban y a la vez negaban el orden social preexistente. No se puede hablar de que cumplieron una sola función, dado que la versatilidad de su oferta - material y simbólica - la sitúa en un campo de juego muy cambiante. En sus dominios ocurrieron - aunque la mayoría de las veces por corto tiempo- subversiones que amenazaban la estructura dominante, aun cuando tampoco se puede afirmar que fungieron como una utopía. Sus retazos dan indicios de una formación heterotópica, donde el desorden «hace brillar los fragmentos de un gran número de órdenes posibles» (Foucault, 2010:36).

Una de las principales quejas contra la pulpería fue su desorden. Y no solo con respecto a la profusión de gentes diversas que no debían socializar, sino también por la disposición de productos, sabores y olores, en apariencia, altamente contradictorios. Qué mayor desorden que el guarapo expendido en estos locales:

Una mezcla de azúcar ordinaria — llamada papelón — con agua. A las veinticuatro horas de hecha esta mezcla comienza a fermentar y se convierte en una bebida muy aceptable si se toma fresca, pero se hace más fuerte mientras más se conserva, en cuyo caso adquiere un sabor agrio, desagradable para el extranjero, pero muy del agrado de los indios y mulatos, debido a su mayor fuerza alcohólica. (Semple:35)

Combinación que hacía estragos entre gente mezclada y creaba numerosos inconvenientes a las autoridades, ya que la embriaguez fue uno de los alegatos más empleados para defenderse de reyertas, subversiones y «malos tratos». William Duane, político norteamericano que visitó la República de Colombia entre 1822 y 1823, pudo ver que en una pulpería de Las Adjuntas «de las paredes colgaban velas de sebo, y los demás artículos estaban expuestos, sin mucha preocupación por su orden y buena presentación, en pesados armatostes» (131); eso, además de ajos, morcillas y pudines que llamaron poderosamente su atención. Otro agente norteamericano llamado Richard Bache, quien también visitó la «Gran Colombia» por estos mismo años, expresa su sorpresa ante la forma poco ordenada de exhibir «carnes preparadas, salchichas, frutas y legumbres, pan, tabaco y otros artículos» (95). La palabra del inglés John Hankshaw para describir lo que observó en una pulpería venezolana hacia mediados de la década de 1820 fue: «aglomerado» (102). Combinaciones que podían afectar a los olfatos no acostumbrados a la lenta pero continua descomposición de alimentos al interior de estos espacios, tal como señala el citado Karl Appun en 1849. Su visita a una pulpería de Valencia le hizo quejarse del «aguardiente de olor repugnante y a una carne seca parecida al cuero de suela» (Appun:236).

Esta porosidad que se desplaza constantemente del orden al desorden, de la civilización a la barbarie ${ }^{10} \mathrm{y}$ de la memoria al olvido, refleja que esta aparente desorganización es portadora 
«de una infinidad de posibles, de una fecundidad inagotable» (Balandier:44). Y en esa delgada franja que podía definir la victoria de la derrota y la vida de la muerte se movían sus asistentes. En las pulperías se vivía al límite: «Cuando llegamos a la pulpería de Ernandes oímos un gran ruido y vimos en el patio una pelea terrible a machete; los que peleaban eran negros y mulatos" (Bellerman:59). La frontera entre obtener un favor y resultar herido de muerte era casi imperceptible, y estaba mediada por la capacidad de negociación de los asistentes, quienes debían observar cómo las jerarquías sociales se reconfiguraban dentro de este espacio. Algunas de estas prácticas fueron: «Pagar las apuestas, no hacer trampas en el juego, evitar el escándalo, calmar al ebrio violento, aceptar la invitación de una copa, retirarse cuando el pulpero cerraba las puertas del local» (Parolo:136). Los chistes eran comunes, así como las mofas hacia quienes perdían en la gran cantidad de juegos allí desarrollados; acciones que con un consejo mal dado, o un trago de más, podían llegar a convertirse en una guerra a muerte. A pesar de que funge como un espacio de libertad, «afuera igualitario» donde ya no era preciso callar, en la pulpería también había que cuidarse; un mal comentario podía desatar graves inconvenientes, más con temas álgidos como el político o el étnico.

Un pleito entre un moreno miliciano y unos indios en el pueblo de Turmero hacia julio de 1800 adquiere rumbos imprevistos. Lo que pudo resolverse con una multa hacia el pulpero — por estar abierto luego de las nueve de la noche- $-\mathrm{y}$ un escarmiento hacia las partes, ahora llegaba a oídos del Rey. Y es que el moreno Sabino Brito dijo «que no estaba dispuesto a compartir su esparcimiento con personas de inferior calidad, porque pronto dejaría de ser pardo y merecía una atención más exclusiva en la guarapería» (Pino Iturrieta:3-4). Se podría decir que en estos microespacios «una plebe inquieta elaboraba la síntesis de sus colores» (Díaz Sánchez, 2003:391).

Las pulperías se debaten entre transgresión y utilidad. Es donde se juega, se asesina, se contrabandea y donde se mezcla lo que debería estar separado por sexos y estamentos, pero también donde se obtiene lo necesario para sobrevivir. Allí pueden gritarse ciertas cosas que en el «exterior» no serían muy bien recibidas. Tampoco significó que escaparan al influjo de la sociedad donde se encontraban, y aunque los asistentes quizá obtuvieron algunas comodidades y liberaron pequeñas tensiones, tuvieron que manejarse como quien lo hace en un campo minado. Pero ese mismo «desorden» que sirvió para generar una igualdad, la mayoría de las veces efímera, pero muy significativa simbólicamente, era justamente el que intentaron aprovechar los asistentes y dueños de estos lugares.

Desplazarse en una pulpería requirió de variadas «tácticas» que aprovecharan el incierto estado de las cosas, pero sin «ilusiones de que [todo] vaya a cambiar de pronto» (De Certeau, 2000a:31-32). Un estilo de economía moral, donde la dádiva y la tenacidad — para rechazar de distintas formas el orden establecido- se entremezclan e intercalan de acuerdo con el momento." Sencillamente «la vida no puede sentarse en ella para estancarse» (Benjamin, 2013:25). La táctica «no guarda lo que gana» (De Certeau, 2000a:43); es efímera, pero con la fuerza necesaria para crear fisuras en el plano material y simbólico imperante, como cuando un negro borracho y alegre se atrevía a faltarle el respeto a un mantuano que seguramente lo azotaría. Sin embargo, el choque de esas frases, pronunciadas en medio de una pulpería, sirvió para relativizar la relación de dominio que allí debía preponderar. La duda es nociva para el poder, más cuando esta se convierte en «buenas pasadas del "débil" en el orden construido por el "fuerte", arte de hacer jugadas en el campo del otro, astucia de cazadores» (46). 


\section{"Gente fea y peligrosa»}

La República imponía crecientes retos, y uno de ellos era tratar de controlar de una vez por todas a la inquieta y subversiva pardocracia, punta de lanza de una sociedad mulata que exigía mayor participación en el nuevo orden. Aparte de crear mecanismos económicos para integrar a la República con el sistema capitalista mundial, erigir una Historia Patria que justificara la gesta independentista e inventariar el territorio nacional, luego de 1830 era menester crear «la geografía de la barbarie» (González Stephan 1995:448). A la barbarie había que tipificarla, tenerla ubicada, aunque este concepto no fuese preciso, ya que casi siempre se definía por ser lo contrario al modelo civilizatorio. Esta delimitación escondía un miedo. La condición mezclada y heterogénea de los «bárbaros», una que les permitía colarse en los bailes, discutir en las pulperías y caminar por las plazas con altivez.

Estos intentos no eran nuevos. Una Ordenanza del 23 de noviembre de 1775 establecía la creación de Alcaldes y Celadores de Barrios en Caracas, dado el vertiginoso crecimiento demográfico de la ciudad, pero también porque en estas adscripciones hallan «cómodo refugio los vicios; los esclavos fugitivos y vagabundos acogida: mal cumplida la observancia de lo que se manda, y otros más, perjudicándoles males, que todos serán remediados, por el celo inmediato de estos comisionados». ${ }^{12}$ El Alcalde tenía la responsabilidad de velar por el buen funcionamiento de su Barrio, y una de las tareas fundamentales era «llevarle el tiempo a las pulperías», donde se violaban de forma continua «la moral y las buenas costumbres». Debían saber en qué momento se armaban las peleas, cuáles días ingresaba la mercancía contrabandeada, y a qué horas se leía y debatía sobre asuntos prohibidos. Así:

No es de menos importancia que se celen los figones, guaraperías, bodegas, pulperías y casa de juegos por lo que los Alcaldes de Barrio, que las tendrán especificadas con toda distinción en su asiento, las visitarán a diferentes horas, y repetidamente instruyéndose del número y calidad de los concurrentes, sin excepción de clases, observándose qué desórdenes se cometen, qué altercados haya, y por qué motivos, como también si se cierran y desocupan dichas casas a las horas que corresponde a casa uno. ${ }^{13}$

Si bien la pulpería no siempre significó un atentado directo contra el poder establecido, su germen revolucionario tuvo de cabezas a muchas autoridades que buscaron disciplinar su funcionamiento. El manejo de los horarios fue un mecanismo muy importante para controlar los excesos, ya que si eran complicados con la luz del día, la noche les ofrecía un perfecto camuflaje. Por ello en 1735, el Gobernador don Martín de Lardizábal, a través de un Bando de Buen Gobierno, decretaba: «Que todas y cualquiera personas se recojan a las nueve de la noche, en sus casas y posadas, pena de seis pesos aplicados por tercias partes a la Real Cámara». ${ }^{14}$ Cinco años más tarde, otro Bando destinado a la ciudad de Caracas, volvía a recordar que la hora tope para expender y socializar en las pulperías era las nueve de la noche, a lo que también agrega: «Que ningún pulpero, mercader ni otra persona alguna compre alhajas ni otras cosas de esclavos», ${ }^{15}$ dado que al parecer, a esas horas, muchos aprovechaban para cambiar efectos -algunos de ellos robados- en estas tiendas. Numerosos pulperos dejaban de preguntar por la procedencia del objeto, para centrarse en la negociación que le proporcionara la mejor parte.

Pero dicho contrabando también trajo consigo ideas y debates de gran envergadura. Por ello el francés J.J. Dauxion Lavaysse, quien se sintió desconcertado por la forma en la que se distribuía 
la propaganda sediciosa en Cumaná para 1807, relata: «entré un día en casa de un pulpero a quien encontré ocupado haciendo cucuruchos y bolsas con las Declaraciones de los derechos del hombre, ejemplares del Contrato Social y Bulas, verdaderas o falsas, del Papa Pio VI excomulgando a la nación francesa» (215).

Había obtenido el material en un viaje a Trinidad, donde regalaban estos paquetes a todos los contrabandistas. El trato desdeñoso dado a los papeles seguramente no reflejó la intensa discusión que generaron, donde pudo haber reforzado particulares ideas de libertad e igualdad entre los asiduos visitantes. Asimismo, debemos resaltar la capacidad de los pulperos para conseguir informaciones y mercancías por cualquier vía. Conocedores de las redes comerciales lícitas e ilícitas, siempre pujaban para hacerse con la «novedad» del momento, luego ofrecida pomposamente en su peculiar microcosmos.

$\mathrm{El}$ alardeo fue una de las condiciones indispensables para quienes asistieron a la pulpería. Aparentar saber, jugar, pelear, pero también hacerse el que no sabe. Esto no significa que en estos espacios no hubiera ningún elemento de «verdad», solo que: «Se sabe que no se tiene derecho a decirlo todo, que no se puede hablar de todo en cualquier circunstancia, que cualquiera, en fin no puede hablar de cualquier cosa» (Foucault 1992:11-12). La presencia de un «discurso oculto» (Scott), donde los dominados expresaban todos sus resquemores hacia los dominadores, se presenta a medias dentro de las pulperías. Claro que estos espacios proporcionaban cierta comodidad a sus asistentes, pero tampoco la suficiente como para confiarse. Este «discurso oculto» se parece más a una mesa de juego que a la proclama política. A veces un gesto, una mirada entre líneas, la carta marcada, el miedo a la derrota, pero la certeza de quien tiene su pobre destino en las manos. Todos aspectos que parecen nimios e irrelevantes, pero que nunca dejaron de preocupar: «Que el pueblo no tiene criterio ni opinión, bien está, pero entonces, ¿por qué una policía completamente organizada alrededor de la captación de los murmullos y clamores de la ciudad, de la observación de la calle y de los rumores que hacen estremecerse su superficie?» (Farge, 1991:80).

Quizá porque el ruido, si bien no convence, por lo menos aturde. De eso acusaban a don Luis Laya, pulpero de la villa de Araure en 1798: de aturdir la conducta de los indios Guamos. La condición jurídica del indígena desde comienzos de la conquista fue la de un menor de edad, alguien que necesita tutelaje y que podía ser reducido «fácilmente» en demarcaciones territoriales. Pero las condiciones de este lugar, habían logrado que los indios se «arrochelaran sin temor». ${ }^{16}$ Las cumbes o rochelas, asociadas primordialmente con la población esclava, tuvieron una diversidad tal que en sus itinerantes filas desfilaron zambos, pardos, indios, mujeres, bandidos y cualquier otro personaje prófugo de la justicia o de adversas condiciones laborales. Más allá de la revuelta por venir, la fuga de esclavos y la libre circulación de jornaleros desafiaban las máximas laborales de la época. La vagancia era la madre de todos los males, y la pulpería se encargaba de fomentarla. La pulpería urbana, ubicada en las esquinas, «robaba» el tiempo medido de los siervos y esclavos, quienes se llevaban como plus una borrachera o un nuevo argumento para desafiar $-\mathrm{y}$ a veces solo satirizar - sus adversas condiciones de vida. En el caso de las pulperías rurales, a mitad de camino, pudieron haber recibido a numerosos jornaleros relajados y esclavos prófugos.

Si hubo territorios reacios a los cánones políticos y morales, esos fueron los Llanos de Caracas, lugar donde se refugiaron esclavos fugados, indios, pardos y toda clase de hombres inconformes con las relaciones de explotación a las que estaban sometidos. Sus costumbres eran mal vistas desde la capital, donde se hablaba de unos seres vulgares sin respeto de Dios, que vivían 
amancebados y robando todo a su paso. La conquista de los Llanos a partir de la segunda mitad del siglo XVIII afectó directamente la vida en estas regiones. Lo que antes podía tomarse libremente por ser "cimarrón», ahora formaba parte del caudal de un mantuano caraqueño. Esta hegemonía llegó a tal extremo, que el Consulado de Caracas, para lavarse las manos ante las constantes quejas de los ganaderos, agrega: «puede decirse que los valles por entero son suyos».

Con la finalidad de regir el comportamiento y en aras de hacerse con una mano de obra barata, los nuevos propietarios redactan algunas disposiciones: «Que ninguna persona escotera pueda andar por caminos extraviados, sino por los trillados y reales, pena de 25 pesos (...) y siendo persona de baja esfera se le darán 100 azotes y será condenado a dos años de presidio». Así reza un apartado de la Ordenanza de Llanos de 1773 (Izard, 2011:141), donde se observa el espíritu excluyente que la sustenta. Tener pasaporte y la venia de algún hacendado o ganadero importante de la región eran requisitos indispensables para no ser tenido por delincuente.

El trabajo era una virtud, de eso no había dudas, así fuese una jornada de 14 horas. Por lo tanto, lo que un pagano era para el orden divino, un vago lo representaba para la religión laica del progreso. Por ello la pulpería, lugar donde más que reunirse, las personas se amancebaban, fue tenido por aquelarre. El delito de vagancia fue penado con azotes, pero también con la recluta y el trabajo en obras públicas; penas que recayeron sobre los estratos bajos e intermedios de la población. Así: «El discurso sobre la ociosidad, por tanto, era una teoría antropológica ya que, si se era catalogado de ocioso, por naturaleza se era capaz de cualquier vicio, pecado, desorden o delito» (Araya Espinoza:18).

Un esclavo o un jornalero libre sentado en una pulpería, malgastaba tiempo precioso, tiempo que no le pertenecía. De los vagos, hacia 1822 en la población de Río Chico, se decía: «eran entregados a la perversidad acompañada del ánimo bárbaro que en ellos reside». ${ }^{17}$ El perjuicio de que un jornalero abandonase una hacienda para trabajar en otra residía en el incumplimiento de sus labores, pero también en el hecho de sacar un dinero que debía ser gastado exclusivamente dentro de esos espacios, ya que numerosas haciendas contaron con pulperías propias, esto sin contar que si volvía trayendo otras noticias, como mejores pagos y condiciones laborales, el hacendado se podía quedar sin mano de obra. También denunciaron la embriaguez que inhabilitaba para el trabajo, pero que soltaba la lengua para denuncias y fantasías igualitarias. Por ello algunos hacendados de La Victoria reconocieron a mediados de 1797, gracias a una pulpería del Buen Consejo, que:

Es en grave manera perjudicialísima porque como allí no se expende otra cosa que guarapo, aguardiente, tabaco, algunas velas y jabón no es otra cosa aquella casa que expensa de vicios y rochelas en donde se entretiene el peonaje que trabaja en el cultivo de aquellas haciendas, y privándose de los sentidos faltan a tan laudable ejercicio, a que se agrega las continuas quimeras que allí se ofrecen. ${ }^{18}$

Ante la excesiva vigilancia, dentro de las pulperías se las ingeniaron para continuar bailando, bebiendo, jugando o conspirando. El soborno a la autoridad y la presencia de una sala oculta, fueron opciones válidas para distraer la atención, así como propiciar la «falta en algunas tiendas, bodegas y pulperías de los faroles que desde los antiguos bandos de buen gobierno se ordenaban». ${ }^{19} \mathrm{La}$ oscuridad, se pensaba, es el complemento de las fechorías, y para muchos, beneficiaba el escape de los mayores truhanes, de los que se podían camuflar con la noche: los negros. 
De José de la Concepción Medina solo se sabía que era un negro libre, natural y vecino de Curiepe, que se preciaba de "guapetón y provocativo, y anda de pulpería en pulpería buscando quimeras y provocando a todos, y con una baraja provocando a varios para jugar juegos prohibidos», ${ }^{20}$ hasta que el 28 de octubre de 1803, lo encontraron peleando fieramente con un puñal en una pulpería de Chacao. Costó mucho doblegarlo, ya que su corpulencia y el diestro manejo del arma puso en apuros a las autoridades, habilidades que tal vez adquirió con el reo Andrés Gelder, de quien se decía era su amigo, y que se juntaban con «otros vagamundos y se metían hasta entre los montes a jugar juegos prohibidos; que el dicho José María Concepción es un gran Baladron, provocativo y hombre de muy mala y desarreglada conducta». ${ }^{2}$ El problema no era la noticia de otro pleito en una pulpería, sino verificar que estos sectores de la población estaban fuertemente armados, y que para fines del siglo XVIII y comienzos del XIX estaban buscando algo más que una mejora en el jornal.

El hito de Haití, la revuelta de José Leonardo Chirino de 1795 y el rumor que desde 1789 se corría, de que con la Cédula de educación y trato de los esclavos, el Rey les había otorgado la libertad, pero que las elites locales no querían dar la noticia, había cosechado un malestar muy grande en las haciendas, pero también en las calles, gracias a la cantidad de libertos y esclavos urbanos que las recorrían. Influenciar a esta capa inestable y peligrosa de la sociedad fue agenda importante en la política venezolana desde finales del XVIII. Las Ordenanzas de Gual y España, el proyecto mirandino, la conjura mantuana de 1808, José Tomás Boves en 1814, Simón Bolívar luego de 1815, Manuel Piar en 1817, Antonio Leocadio Guzmán a partir de 1840 y Ezequiel Zamora luego de 1846, muestran los diferentes rostros de un fuerte descontento social, que en no pocas ocasiones fue utilizado para crear mayor sufrimiento.

Y estas elucubraciones y prácticas, de unos negros que estaban construyendo su concepto de libertad, se potenciaron con el inicio de la guerra de independencia. Más que enfrentar «patriotas» $\mathrm{y}$ «realistas», «españoles» $\mathrm{y}$ «americanos», dicho proceso ponía en escena fuerzas que estaban chocando desde tiempos coloniales. Una «guerra civil» (Vallenilla Lanz) que puso ideas «novedosas» y armas mortales en manos de quienes nunca lo hubiesen imaginado. La oportunidad de cambiar la suerte, de trastocar el fondo de la sociedad, de adquirir el pedacito de patria que se prometía en tantas proclamas. De lograr una movilidad rápida y violenta o morir en el camino, de eso se trataba para muchos. Dudas y certezas que eran discutidas en las pulperías.

"Que el día de Pascua se cantaba la Patria en Caracas»:22 estas fueron las palabras que Josefa Meneses, esclava mulata y natural de Coro, encontró para callar las quejas de Juliana Meneses y Nicolasa Laya, mientras recorrían el camino desde Caracas a Ocumare de la Costa, en noviembre de 1815. Esa "patria» iba a resolver todos sus problemas, por ello convidaba a sus conocidas para que se «aprovechasen del saqueo de Caracas». ${ }^{23}$ Estas ideas las había escuchado de un zambo bastante efusivo, tenido por «insurgentísimo», y que repetía sin cesar que iban a "pasar a cuchillo todos los españoles y criollos leales al Rey». ${ }^{24}$ Según los testigos, Francisco Luis vivía en la pulpería que Eusebio Acosta tenía en el sitio de la Palmita en Caracas, donde se reunían varias personas para hablar de planes revolucionarios y de la posición que había que tomar, donde «no había remedio sino ser patriota». ${ }^{25} \mathrm{La}$ "patria» de Francisco Luis y los otros asistentes a las reuniones pasaba por aprovechar el botín y cobrar viejas rivalidades locales.

Al final, los implicados son liberados, Francisco Luis se da a la fuga, y solo se castiga a la esclava Meneses, que en noviembre de 1815 recibe 25 azotes de dolor. ¿Es posible que la boca de esta desafortunada estuviera anunciando el desembarco que realizara Simón Bolívar en Ocumare 
de la Costa en julio de 1816, o solo se trataba de otra fantasía igualadora propia de estos «malentretenidos»? Tal como la sucedida el 26 de noviembre de 1815 a las ocho de la noche en la Plaza Mayor de Caracas, donde las autoridades se movilizaron gracias a los cantos y bailes de una «chusma» compuesta por el pardo libre Manuel Aguado, «el cojo» José Antonio Morales, Victoria Villegas alias «el piquirico», y el sastre esclavo de nombre Ramón, entre otros, quienes decían: «El general Bolívar tiene un caballo para matar españoles europeos y canarios». ${ }^{26}$

Durante la guerra de independencia las elites de los partidos en pugna trataron de mantener cierto control sobre los estratos bajos e intermedios de la sociedad, a sabiendas de que era la única garantía de que ese archivo de resentimiento que estaban azuzando no se volviera contra ellos. Así, la Primera República emite dos leyes que buscaron limitar la movilidad de la población, algo que ya se avizoraba peligroso. La primera es un Bando de Policía aprobada en enero de 1811, la cual ante un clima de gran inestabilidad, buscaba inventariar y controlar. Por ello establecía que las bodegas, pulperías, fondas y salas de juegos cerraran a las 10 de la noche, evitar comprar efectos robados a negros y mulatos, así como promover el desarme de estas "gentes»; todo para impedir que «se introduzcan en esta ciudad vagabundos, delincuentes, personas sospechosas». ${ }^{27}$ Estipula que la madre de los males era la ociosidad, razón por la que los Alcaldes debían pasar rondas y reconocimientos diarios para evitar la presencia de estos «indeseables».

La segunda ley se trata de la Ordenanza de Llanos de 1811, que buscaba controlar la mano de obra y fortalecer la propiedad privada en estos territorios, reacios a los ordenamientos que se expedían desde Caracas. Así queda registrado en el Título II, sobre «Arreglo de la gente de servicio, y transeúntes», específicamente en su artículo 3:

Se prohíbe expresamente el que persona alguna transite por los Llanos, sin que acredite por guía o pasaporte que le darán en papel de estampilla graciosamente los jueces, el paraje de su salida y el de su destino; y en el caso de encontrarse alguno sin este documento se le asegurará en la cárcel hasta hacer la competente averiguación de quién es y resultando ser delincuente, se le aplicará la pena que corresponda a su crimen; y, de lo contrario, la de diez pesos al que pueda exhibirlos, y al que no, la de cincuenta azotes como contraventor de estas ordenanzas, con duplicación de las penas en caso de reincidencia, excepto las personas conocidas..$^{28}$

Esta presión hacia una gente conflictiva y heterogénea, sumada a condiciones económicas adversas, hizo que ese «bravo pueblo», que figuró en tantos documentos oficiales entre $1810 \mathrm{y}$ 1812, fuera el primero en engrosar las filas de José Tomás Boves, pulpero y contrabandista que promete el esperado botín entre 1813 y 1814. Si bien Boves encarna victorias contundentes para el bando realista, lleva consigo el germen de la destrucción. Sabía dirigir a hombres muy diversos y peligrosos que solo obedecían sus órdenes, creando una especie de equilibrio inestable difícil de entender, tal vez enfrentando situaciones a las que un pulpero estaba acostumbrado. Con el asesinato de José Tomás en diciembre de 1814 muere una forma de hacer la guerra y emerge el deseo de controlar todo lo que recuerde su nombre.

Para numerosos realistas, el arribo a Caracas de Pablo Morillo - mayo de 1815 — significaba un nuevo comienzo: el que borraría las atrocidades propias y extrañas para difundir con ímpetu los cánones monárquicos. Con el «Pacificador», no solo llegaban las órdenes de un Rey recién establecido que deseaba «reconciliarse» con sus súbditos más reacios, sino el ejemplo de lo 
sucedido con los liberales de la Península. Dicha tabula rasa debía acometerse desde todos los flancos; por lo tanto la Gaceta de Caracas del miércoles 1 de febrero de 1815 expresa: «Condenemos a un eterno olvido ese funesto delirio que tanta sangre, luto y lágrimas ha costado».

Podríamos aseverar que dichas acciones llegan a su cenit a mediados de julio, cuando se expide un «Reglamento General de Policía para las Provincias de Venezuela». Quizá uno de los puntos más interesantes de este corpus, que buscaba normar varios aspectos de la sociedad, fue aceptar de antemano que la violencia de las armas y los principios morales no eran suficientes para asegurar la paz en unos pueblos que la habían perdido. Dicho reglamento necesitaba:

[E]stablecer una nueva «economía» del poder de castigar, asegurar una mejor distribución de este poder, hacer que no esté ni demasiado concentrado en algunos puntos privilegiados, ni demasiado dividido entre unas instancias que se oponen: que esté repartido en circuitos homogéneos susceptibles de ejercerse en todas partes, de manera continua, y hasta el grano más fino del cuerpo social. (Foucault, 2008:93-94)

Por ello, dichas Ordenanzas ponían especial atención en las reuniones que se desarrollaban en las pulperías; lugar donde abundaban las quejas, al igual que las conspiraciones. Pablo Morillo no contaba con la venia popular. Había llegado suprimiendo el botín, limitándolo a su círculo más cercano. Más de uno fantaseaba con la llegada de la Patria, concepto que tomó muchas formas, pero que en ese momento significaba la salida de Morillo y la restitución de un sistema de reparto donde se habían visto reflejadas las grandes mayorías. De esta forma:

A ninguna persona de cualquier estado, clase y condición que sea, le será lícito sin permiso de autoridad legítima tener en su casa u otro lugar, pública o privadamente, a horas regulares o intempestivas, ni asistir a reuniones diarias o frecuentes, sospechosas al Gobierno por ello, o sin esta razón por la clase de gentes de que se componen. ${ }^{29}$

Y este miedo no era infundado. Si bien hacia 1815, en Caracas había una parte considerable de la población que estaba a gusto con los realistas, también existía la incisiva amenaza de sus contrarios. Prueba de ello fueron las expresiones que desde una pulpería ubicada en la caraqueña esquina de Camejo profirió el barbero pardo José Manuel Gamarra, quien para mediados de 1815 contaba con 46 años. Palabras más, palabras menos, cuentan que Gamarra entró a la pulpería por comida, y que solo bebió un poco de aguardiente, lo que no melló su deseo de gritar: «Carajo, si este es Gobierno no lo quiero; que el Ejército que ha venido de España a tranquilizar no hace más que matar a todos, robar y atropellar a cuantas mujeres encuentran ¿esta es Ley de Dios? Yo soy para mi Patria..$^{30}$ Luego dio un estado detallado de la resistencia que los patriotas daban en Cartagena de Indias, azuzando las esperanzas de una pronta invasión. Dichas amenazas, en medio de la pulpería, le costaron la vida. Gamarra sería ahorcado el 19 de diciembre de 1815 a las 11 de la mañana en la Plaza Mayor de Caracas. Quizá por atrevimientos como este, en septiembre de 1816, la Real Audiencia de Caracas legisla sobre un tema ya recurrente: estima por oportuno y arreglado «al pensamiento de Vuestra Señoría sobre publicar bando, imponiendo la pena de cincuenta azotes a la persona de color que se encuentre con garrote, 0 asta de lanza». ${ }^{31}$

Si bien entre 1813 y 1815 se muestra la cara más violenta de la «Guerra a muerte», esta violencia siguió su curso durante gran parte del siglo XIX, quizá no ya como ejércitos beligerantes, 
sino como partidas de bandoleros que hacían valer su fuerza en espacios locales. Luego de 1821, la ciudad de Caracas vuelve a manos republicanas. Habían pasado siete largos años de aquella funesta emigración que había sacrificado tantas vidas, pero muchas de las tensiones socioeconómicas que la habían propiciado parecían estar latentes en las calles, y según las previsiones, con mayor fuerza en las pulperías. De aquí el extremo cuidado que pone un Bando de Policía de Caracas, promulgado en 1824, sobre el control de vagos en cada uno de los cuarteles de la ciudad. Personas que no contaran con oficio ni ocupación certificada, o en su defecto, con un pasaporte que justificara su ausencia, perfil que seguramente no cumplía una gran parte de los asistentes a las pulperías. En consecuencia: «El pulpero, ventero o mesonero que no los delate al inspector de su cuadra, pagará dos pesos de multa por la primera vez, cuatro pesos por la segunda, y privado de poder vender en dos años por la tercera». ${ }^{32}$ Pero esto era en el papel. Un pulpero no podía darse el lujo de aparecer como un delator, y si lo hacía, debía cuidarse mucho.

Para ciertas explicaciones historiográficas, durante estos años álgidos de construcción de una República, «los de abajo» estarían condenados a llenar un molde predeterminado. De esta forma, si un negro no es Pedro Camejo, un pardo Pedro Arévalo, un indio Guaicaipuro o una mujer Luisa Cáceres de Arismendi, estarían traicionando el «espíritu» de la independencia. Olvidando así que «ni las formas cotidianas de resistencia, ni la insurrección ocasional se pueden entender sin tener en cuenta los espacios sociales cerrados [pero no autárquicos] en los cuales esa resistencia se alimenta y adquiere sentido» (Scott:45); y una de las expresiones más acabadas de esta sociabilidad fue "gozar de alguna venganza sobre sus opresores imaginando sus futuros tormentos» (Thompson, 2012:56).

Venganza que llevaban las palabras que escuchó Vicente Arias el 20 de diciembre de 1822. Luego de una ardua jornada de trabajo, Arias se dirigió a una pulpería situada en la esquina del Muerto, con la finalidad de tomar café y conversar un rato. A su lado estaba un hombre que insistía en invitarle, y tanto fue el empeño que Arias aceptó; pero con el café también llegó una terrible confesión, pues ese hombre, que llevaba el nombre de Juan Antonio Durán, le dijo que «tenía que irse a causa de que su mujer la tenía en el monte de Santa Lucía, pues la Nochebuena se iban a degollar a todos sin excepción de persona, fuese español o isleño».3 ${ }^{33}$ Durán se identificaba como miembro de la partida de Dionisio Cisneros, indio guerrillero y bandolero que decía defender los últimos vestigios realistas, pero que también reclutaba a negros, zambos e indios bajo la promesa del botín. Aunque este hombre alegó su estado de ebriedad para tratar de convencer a las autoridades, estas declaraciones no representaban una sorpresa para una sociedad que todavía sufría los embates de la "guerra de colores». Su vigencia fue demostrada en diciembre de 1824, justo cuando el pueblo de Petare fue atacado por 200 hombres, esclavos y hombres libres armados de machetes y algunas carabinas, facción que buscaba apoderarse del parque existente, y que sin embargo fue rechazada por la guarnición, algo que reforzó una medida muy vieja: «que por la noche al venir estas de sus trabajos se les recojan las herramientas y cualquier arma de fuego que puedan tener».34

Esta constante inestabilidad política y social pudo haber inspirado la ley del 3 de mayo de 1826, sobre procedimiento en las causas de hurto y robo, sancionada por el Congreso de la República de Colombia. Ella se justificaba en: «Que por una consecuencia de la dilatada guerra que ha sufrido la República cierta clase de hombres se ha desmoralizado hasta el extremo de atacar frecuentemente del modo más escandaloso la propiedad y seguridad individual del pacífico 
ciudadano», ${ }^{35}$ situación que los legisladores atribuían a la preocupante cantidad de vagos y malentretenidos que pululaban bajo la mirada cómplice de las autoridades, y especialmente en las pulperías, lugares que eran denunciados por acoger y aprovisionar famosas partidas de bandoleros en todo el territorio.

«Preguntado si en la pulpería de que estaba encargado entraron facciosos: dijo que entraron sin ocultarse»: ${ }^{36}$ así contestó Juan Bautista Álvarez, esclavo de Julián Álvarez, a las autoridades que le interrogaban sobre la actuación de facciones que operaban entre los pueblos de Los Teques y Paracotos en septiembre de 1827. Tampoco tuvo problemas en aceptar que en dicha pulpería se aprovisionaban de víveres. En estos casos, numerosos pulperos fueron acusados de cómplices, cargo que a veces resultaba cierto, pero que en otras, solo era cuestión de sobrevivencia. Tratar con las partidas de bandoleros, abastecerlas y darles facilidades de pago, eran medidas que podían traer beneficios concretos en una época de extrema violencia. Un ejemplo lo podemos encontrar con un saqueo que la partida de Dionicio Cisneros realizó en el pueblo de Santa Lucía hacia 1824. Allí, entre otras acciones, robaron la pulpería de Román Laya, dejando intacta la de Julián Matamoros que estaba al lado. Ante dicha curiosidad, las autoridades interrogaron a Gerardo y Tiberio Jaspe, hombres de Cisneros capturados durante la acción, a lo cual respondieron: «que la orden que tenían de Cisneros era solo de saquear la del ciudadano Laya porque el otro señor de quien se le hallaba había dicho su mismo Capitán (Cisneros) que era muy hombre de bien y que además su amigo». ${ }^{37}$

«Que había ganado con ellos más de dos mil pesos, y que ojalá siempre estuvieran entrando, pues le había ido muy bien», ${ }^{38}$ fue la respuesta del pulpero catalán al que todos le decían don Juan en la localidad de Cuyagua. Corría el año de 1816 y la presencia de las autoridades realistas se debía a la continua presencia del bandolero Domingo Udi, jefe de una efectiva red de aprovisionamiento y espionaje entre Maracay y Turmero. En 1825 acusaron a Luciano Padrón, pulpero del Rodeo de remitir pescado, pan y otros víveres a la partida del ya referido Cisneros. ${ }^{39} \mathrm{La}$ misma queja recayó sobre Santiago Guía en 1826. Era natural del pueblo de Petare y con pulpería establecida en el sitio del Rodeo de los Mariches. Se le imputaba contribuir activamente con Cisneros, ante lo que contestó:

Por el tenor de estas declaraciones se convence positivamente que la facción de Cisneros se proveía algunas ocasiones de víveres de mi pulpería: ¿Y por esto deberá tratárseme como criminal, y cómplice en ella? De ninguna manera. Mi pulpería es una casa pública donde concurre todo el que quiere, y yo estoy en la obligación de venderle por su dinero. ${ }^{40}$

Guía expuso no saber ni de ufacciones ni de jaranas», sino de trabajar con honor para el Gobierno; además, ya pasaba de sesenta años, y esto le imposibilitaba meterse en este tipo de quimeras. Finalmente, el pulpero sería puesto en libertad. Pero no siempre el pulpero se mantuvo al «margen». En muchas ocasiones los pulperos fungían como informadores, y a veces hasta de socios, pues los productos robados y las relaciones en la región podían ser aprovechados en la tienda.

Sin embargo, no todo se redujo al orden de lo inmediato, ya que muchos pulperos albergaron reuniones sediciosas donde se prometía acabar con el gobierno y las injusticias. Eran parte activa de las rebeliones, y esperaban cambiar su suerte al golpe del cañón. La revuelta del 11 de mayo de 1831 puede ofrecer algunos indicios. Dicho movimiento tenía como principal objetivo tomar 
la cárcel de Caracas para incorporar detenidos, asaltar el arsenal y tomar el poder. ${ }^{41}$ No obstante, desaprovechan el factor sorpresa y son derrotados con relativa facilidad, no sin antes haber ocasionado un clima de temor en toda la ciudad, y más en sus vecinos principales, quienes se reúnen en la Iglesia de San Francisco para combatir a los alzados. Ahora bien, este movimiento tenía otras motivaciones. Y es que su líder, Juan Bautista Betancourt, pardo libre caraqueño que se desempeñaba como maestro pintor, junto a una serie de morenos y pardos, casi todos albañiles, buscaban deponer la recién instalada República de 1830, pues «no marchaba bien: que mejor era la de Haití, en donde se apreciaba el color que aquí se despreciaba: que allí no había esclavos».42 Al parecer estas ideas, así como el advenimiento de la rebelión, se ventilaban en la pulpería de Felipe Linares, quien contaba con una partida de bandidos «que había organizado para robar los campos». ${ }^{43}$ Según numerosos testigos, la pulpería de Linares también era empleada para repartir el botín y celebrar los asaltos. Aunque la Constitución de 1830 hablaba de ciudadanos, muchos integrantes de los estratos bajos e intermedios estaban recurriendo a estos mecanismos para hacerse notar, ya que no eran considerados como tales.

Para el pardo José Jacinto Ávila, todo el peso de la sociedad recaía sobre ellos. Por ello el nueve de mayo de 1825 a las ocho de la noche, expuso que los blancos «nunca salían a la guerra» y que por lo tanto se «cagaba en ellos». ${ }^{44}$ La pulpería de Juan Acuña, ubicada en Guatire, estaba llena, y las palabras de Ávila, aunque escandalizaron, obtuvieron cierta acogida, más cuando el pardo expuso que los blancos solo «cuando se veían perdidos era que solicitaban a la plebe»; 45 y por eso debían morir.

Muchos de los implicados aceptaron haber expresado estas palabras, lo cual les acarreó severos castigos físicos, servir en obras públicas y hasta la muerte; pero otros acudieron a ingeniosos recursos con tal de zafarse del problema. «Que hasta las cuatro de la tarde se acuerda de lo que en el día hizo (...) pero que de esta de ahora en adelante por la continuación del licor estaba en un estado de insensibilidad total»: ${ }^{46}$ así se defendió Aniceto Burgos en octubre de 1835, luego de haber expresado en una pulpería de la Esquina de la Palma, que haría salir a «chucho» a los comerciantes, y que después levantaría un grito de reformas en el sitio de Ñaraulí, barrio populoso de Caracas repleto de pardos, morenos y canarios. Declaración que requería de todo el cuidado de las autoridades, más cuando el país aún no se sobreponía a la tensión creada por el movimiento reformista que había enviado al exilio al presidente José María Vargas el 9 de julio, y exigía la restitución de la Gran Colombia, así como la muerte a la «Oligarquía» comercial que estaba socavando los intereses militares.

\section{Contra el nuevo orden}

La guerra de independencia había terminado, pero muchos de los problemas étnicos, políticos, económicos y sociales propios de sus dominios, todavía rondaban por las calles, unos de forma más evidente que otros; y una muestra inequívoca de esto fue el ambiente de las pulperías durante esta época. Si bien la pulpería no sirvió siempre como centro de operaciones para la revolución futura, con objetivos precisos, por lo menos albergó incómodos espasmos para quienes deseaban construir una República nueva, o criticar la vigente. Gritos desesperados sobre un nuevo orden que los pusiera a la cabeza, que acabara con la minoría blanca en un país de pardos, o simplemente para reírse de su triste destino y de sus amos, son gestos dignos de analizar en un territorio fragmentado por luchas civiles de todo tipo. 
Pero si por todas partes surgían rumores de alzamiento, consignas igualadores y de «muertes» a la "Oligarquía», tampoco es menos cierto que este vendaval quiso ser detenido con numerosas leyes que buscaran aumentar el control social. En 1834 la Diputación Provincial de Caracas establece un Reglamento de Policía, donde entre otras cosas tipifica al vago, principal enemigo del progreso. Así, eran reputados por tales: «los que habitualmente se embriagan y se encuentran en por las calles públicas (...), los que (...) estuviesen distraídos en tabernas, en juegos», ${ }^{47}$ así como los jornaleros, oficiales y aprendices que gastan su tiempo en ociosidades. Tal como las Ordenanzas coloniales, este reglamento limita la movilidad de los peones y jornaleros, y exige una boleta justificativa por parte del dueño de la hacienda. Casi todas las descripciones cumplen a la perfección con el tipo de asistente a las pulperías. Con la República no se había cambiado su estatus de «reducto de todos los males». Año que presenció la publicación de la ley del 10 de abril, la cual trajo mucho descontento entre numerosos sectores de la sociedad, que veían inhumano que el Estado entregara al deudor en manos del acreedor sin mediación alguna, solo del mercado.

Las autoridades republicanas seguirían trabajando en el concepto de vago, y esto se puede evidenciar en la Ley de Hurtos que el Congreso aprueba en $1836 .{ }^{48}$ La primera característica de esta condición era la falta de hacienda o renta; es decir, el vago no era propietario y por lo tanto no tenía ciudadanía. A ella seguían elementos como la asistencia a las casas de juego, pedir limosna, su relajamiento en las tabernas, ganar lo suficiente como para dejar de trabajar varios días, ser forastero, vendedor ambulante, hijo natural dedicado a la mendicidad. Toda una gama de propiedades que nos muestran a la categoría como efectivo mecanismo de exclusión social para evitar los «vicios morales y sociales», además de controlar a un sector proclive a la revuelta.

Ahora bien, negar la asistencia y existencia de ladrones y asesinos en las pulperías, sería igual de dañino que enunciar con las leyes republicanas de mediados del siglo XIX que casi toda la población de la provincia era proclive a la vagancia, más cuando el día de trabajo de un jornalero era «de doce horas, de sol a sol y cada día salvo los domingo» (Matthews:41), esto sin contar las altas tasas de mortalidad y las ínfimas remuneraciones. ${ }^{49}$ Una molestia reflejada en la respuesta que ofrece Nicolás Calzadilla, peón de albañilería de 44 años de edad, cuando en 1839 se le preguntó sobre su asistencia diaria a las pulperías: «Trabajo como he dicho cuando puedo y aunque es cierto me embriago, no es todos los días». ${ }^{50}$ Respuesta muy frecuente en estos casos, donde los acusados hablan desde la seguridad que da pagar por el aguardiente que bebían. $O$ desde la osadía que le hizo contestar a José Ventura Espinoza, labrador de La Vega en 1841, ante su acusación de vagancia y portador de armas prohibidas: «que el dicho garrote lo cargaba porque le daba gana, y que él estaba en las pulpería era porque también le convenía, vociferando en alta voz, y en público que ni el Juez ni persona alguna lo cogían a él».51

Quizá lo que más atormentaba a las elites era reconocer la conflictiva diversidad de ese "populacho» con el que quisieran o no debían lidiar, pues aun cuando los despreciaran profundamente, ellos movían las haciendas y engrosaban los ejércitos. Panorama esbozado de forma magistral en una editorial de El Liberal del 28 de mayo de 1836: «Siendo Venezuela, como es, un pueblo nuevo, sin leyes propias, sin prácticas conocidas, y lleno de elementos heterogéneos, necesita con urgencia que los encargados de los poderes supremos sean idóneos para remover los obstáculos».52

Estas tensiones que se presentaban de forma epiléptica en toda la Provincia de Caracas parecieron reunirse en torno a la creación del Partido Liberal en 1840. Más que una doctrina acabada, 
esta agrupación política supo reunir el odio al continuismo conservador, la reivindicación de prebendas sociales olvidadas y el ataque a ciertos personajes de la elite económica para crear un clima de inestabilidad política de gran envergadura. Esto coincidió con la crisis internacional de los precios del café, que desde 1839 estaba mermando los ingresos del país.

El 27 de agosto de 1846, el Diario de Caracas publica un remitido donde se queja de los Oligarcas de La Guaira, quienes en compañía del párroco vociferan por toda la ciudad corrillos para asustar a los vecinos. Palabras más, palabras menos pregonaban: «Aquí lo que se quiere es hacer otro Santo Domingo»; a lo que los liberales que redactaban la nota respondían: «Lo que se quiere, señores, es la alternativa, la igualdad y la soberanía popular». ${ }^{53}$ Los recuerdos de la revolución de Haití, las hordas de Boves, las revueltas esclavistas y las deudas sociales que la independencia no cumplió, fueron ideas que sirvieron para que los liberales y conservadores se enfrentaran durante esta década. Amenazar con la idea de negros saqueando y tomando el poder, eran consignas diarias en una política que primero aterrorizaba y luego, si tenía tiempo, resolvía.

Los enfrentamientos se agudizaron de cara a la campaña presidencial de 1846, donde Antonio Leocadio Guzmán, líder y fundador del Partido Liberal, fungía como fuerte candidato a la presidencia de la República. Las células del Partido se extendieron por toda la provincia, y las pulperías fueron lugares favorables para afiliar nuevos militantes, o para desatar enconadas discusiones. Hacia octubre de 1845, el Juez de El Valle, pueblo cercano a Caracas, se sentía preocupado por las continuas denuncias que llovieron sobre Justo Muñós, «quien ha manifestado públicamente desafección al gobierno y a la clase de los blancos, tratando de mover las esclavitudes de este pueblo». ${ }^{54}$ Según los testimonios, Muños era uno de los más exaltados promotores de la candidatura de Guzmán en las asambleas liberales, de quien se decía "triunfaba de todos modos", victoria que vendría aderezada con la acción de pasar a cuchillo a todos los Oligarcas. También se ufanaba de contar con ciertos «amigos» esclavos que Manuel María Echeandía, otro destacado liberal, promovería en los predios de Río Chico. Justo Muños era pulpero, y ante la pregunta «¿Qué relaciones tiene Usted con los esclavos de las haciendas inmediatas al pueblo del Valle?», respondió «Ningunas otras que aquellas que pueden nacer de mi oficio de pulpero».55 A primera vista, esta relación se limitaría al intercambio comercial, pero bien es sabido que en estos espacios, los esclavos jugaron, bebieron, amaron y pensaron, esto sin contar que desde la independencia, eran empleados para inspirar temor en cualquier conflicto. También recibieron a pequeños hacendados y comerciantes quebrados con las políticas oficiales, y a mayordomos descontentos, quienes tenían la facultad para levantar a la gran variedad de gente bajo su mando. Una revuelta exitosa podía diferenciar a un mayordomo de un futuro presidente. A Muños también lo interrogaron sobre la hora en que cerraba el negocio, a causa de las numerosas reuniones que sostuvo en sus dominios luego de las nueve de la noche, pero astutamente respondió que no había reloj en El Valle que le hiciera cerrar a tiempo. Pese a la gravedad de los cargos, el pulpero liberal salió en libertad.

Este clima de inestabilidad dio pie a una serie de revueltas campesinas de mucha violencia en el centro del país entre 1846 y $1847,{ }^{56}$ acciones en las que se conocería por primera vez y a gran escala el nombre de Ezequiel Zamora, pulpero de Villa de Cura que según los entendidos venía gritando «Tierra y hombres libres», no sin antes haber dejado claro su «Horror a la Oligarquía». Haciendas quemadas, muertes, numerosos enfrentamientos y la promesa del botín, fueron algunos de los matices propios de este movimiento, que pese a ser derrotado con contundencia, 
logró permear las formas de hacer política durante las próximas décadas. Tanto así que en 1854, el presidente José Gregorio Monagas decreta el primer Código de Policía Nacional; es decir, un cuerpo unitario donde se reflejarán las máximas del orden y buen gobierno. Cabe destacar que desde 1811 hasta esa fecha, los códigos estaban circunscritos a una ciudad o provincia. En ese texto, donde se llama a luchar contra la vagancia, se nota la urgencia de la misión, pues el artículo 46 deja sentado: «La policía debe ejercer la más constante supervigilancia para que no haya casas (...) ni lugares destinados a las reprobadas prácticas del desenfreno y del libertinaje». ${ }^{57}$

Aunque, por lo visto, las pulperías fueron espacios para discutir eventos políticos de gran alcance nacional, dichas conversaciones y prácticas estuvieron mediadas por un arte del sigilo. Saber callar en el momento indicado fue igual de importante que empuñar un machete y lanzar arengas libertarias. Una relación del viajero Karl Appun en una pulpería de El Baúl hacia comienzos de 1850 reflejaba la tensión política del momento, pero también la desconfianza de quienes conversaban:

Con mi entrada la viva charla se cerró de pronto, pasando a temas políticos, de los que colmaron todos. "Que si el General Páez ya había desembarcado en la costa», «Que si la revolución contra Monagas había estallado ya», «Que quién era el general que se había puesto a la cabeza de los oligarcas». Me hicieron apresuradamente estas y otras preguntas más, sin que hubiera podido contestar una sola. Después se desahogaron en las mayores maldiciones contra el Presidente Gregorio Monagas y contra Guzmán, así como contra todos los liberales, disgustándose conmigo por no haberles podido satisfacer su curiosidad. (239-240)

Los temas variaron abruptamente, al igual que las filiaciones políticas, más en un país donde las pasiones partidistas se burlaban de quienes pedían «fidelidad». Un escenario político donde las alianzas no eran para lograr estabilidad, sino con miras al enfrentamiento por venir. Así, estamos lejos de afirmar que desde las pulperías se predijeron derrocamientos y rebeliones, pero sí se fantaseó con ellas, y con posibilidades tan diversas, fugaces y radicales como las de sus asistentes. Por ello, «leyendo los registros de la policía, se constata hasta qué punto la revuelta, el desafío o incluso la rebelión, son hechos sociales habituales que la ciudad sabe gestionar, suscitar y cuyas primeras señales reconoce fácilmente» (Farge, 1991:24).

\section{Notas}

1 Es necesario recordar que el concepto de casta fue una categoría creada para darle cierta coherencia al problema de la mezcla colonial, pues: «Se consideran individuos de "castas" o calidad inferior, aquellos en cuya ascendencia existe algún elemento negro. Básicamente, se entiende la mezcla de negros con blancos, que origina mulatos o pardos; y la mezcla de negros con indios que origina zambos. Ello sin entrar en una complicada subclasificación producto de dichas mezclas primarias, que, por otra parte, no tienen gran incidencia legal una vez establecido el origen negro. La clasificación "castas" tiene una connotación oficial en los registros civiles o eclesiásticos. De todas maneras, para finales del siglo XVIII, todos los individuos productos de las mezclas con negro eran, generalmente, denominados pardos» (Pellicer:51). Muchos investigadores han confundido por años el empleo del término «casta» en este contexto, al pensar que se trataba de una división infranqueable y hermética, quizá al estilo de la India. No obstante, el acontecer colonial venezolano está muy alejado de esta concepción.

2 «Abigarrar», en http://ntlle.rae.es/ntlle/

SrvltGUIMenuNtlle?cmd=Lema\&sec=1.0.o.o.o. 
3 «El primer mercado establecido en la ciudad de Caracas» (17).

4 Conjuración de 1808 en Caracas para la formación de una

Junta Suprema Gubernativa, (82).

5 Semanario de Caracas. Domingo 18 de noviembre de 1810, n III. http://200.2.12.132/SVI/hemeroteca/index. php?option=com_content\&task=view\&id=300\&Itemid $=440$.

6 «Entre 1750 y 1850 tal polisemia cubre un amplio espectro de significados tales como: a) Su significación como entidad funcional, territorial y políticamente completa; b) Como conjunto de individuos igualados por ley, poseedores de derechos frente a instancias administrativas del poder político; c) Conjunto estructurado de corporaciones que han pactado con el Rey para establecer e intermediar en un orden político; d) Conjunto de individuos igualados en el derecho y depositario de la soberanía nacional; f) El sentido plural, es decir, "los pueblos" o las entidades constitutivas del reino; y g) El sentido singular del vocablo que lo hace equivalente a nación» (Serrano Páez:164).

7 «La constitución de las literaturas nacionales que se cumple a fines del XIX es un triunfo de la ciudad letrada, la cual por primera vez en su larga historia, comienza a dominar a su contorno. Absorbe múltiples aportes rurales, insertándolos en su proyecto y articulándolos con otros para componer un discurso autónomo que explica la formación de la nacionalidad y establece admirativamente sus valores» (Rama:74).

8 Ver Cecilio Acosta.

9 Más cuando el reto «no consiste en identificar la decisiva desaparición momentánea de la cultura popular, sino más bien considerar, para cada época, cuán complejas eran las relaciones establecidas entre las formas impuestas (más o menos flexibles) y las identidades populares establecidas (permitidas o no)» (Chartier, 1994:43).

10 Aunque en la mayoría de los casos las pulperías fueron catalogadas como tugurios del mal donde se perdía todo principio de civilidad, también existieron testimonios que destacaron su labor civilizadora al servir como puntos de contacto y aprovisionamiento entre caminos rudimentarios e inconexos. Karl Appun hacia 1849, al llegar a una pulpería en El Pao expuso agradecido: «De vez en cuando se manifestaban huellas de civilización y de oficios humanos: solitarias pulperías al lado del camino» (278-279). Para el historiador argentino Jorge Bossio, la pulpería fue «una sucursal de la civilización que retiene valor histórico en función del calor humano que le otorgó el campesino de nuestra llanura» (58). Para León Bouché la pulpería fungía como un mojón civilizatorio que unía con servicios y sociabilidad grandes extensiones de la geografía argentina. Según Rafael Ramón Castellanos, los pulperos tuvieron tanta importancia que debían estar junto al Alguacil y el Misionero en el proceso de fundación y establecimiento de los pueblos en Venezuela y el resto de Hispanoamérica.

11 Para Michel de Certeau «La cultura "popular" sería eso, y no un corpus que pudiera considerarse extraño, despedazado para poder exponerse, tratado y "citado" por un sistema que aumenta, con los objetos, la situación que propicia en seres vivos» (2000a:31-32).

12 AGN, Sección Traslados, tomo 583, años 1775-1807, f. 4.

13 AGN, Sección Traslados, tomo 583, años 1775-1807, f. 29.

14 «Un bando del gobierno colonial». Boletín del Archivo General de la Nación, tomo XLI, julio-septiembre de 1954, nro.165, 414 .

15 AGN, Sección Traslados, tomo XXII, años 1739-1741, f. 2. 16 AGN, Sección Diversos, tomo LXXIII, año 1798, f. 202.

17 AGN, Intendencia de Venezuela, tomo LXXX, año 1822, f. 224 vto.

18 AANH, Sección Civiles, tomo 11-4453-6, año 1797, f. 6.

19 AGN, Intendencia de Venezuela, tomo VI, año 1823, f. 115.

20 AANH, Sección Criminales, tomo A11-C6-D859, año 1803, f. 4.

21 AANH, Sección Criminales, tomo A11-C6-D859, año 1803, f. 3 vto.

22 ANH, Sección Causas de Infidencia, tomo XXVIII, exp. 2, año 1815 , fs. 1.1vto.

23 ANH, Sección Causas de Infidencia, tomo XXVIII, exp. 2, año 1815 , f. 1 vto.

24 ANH, Sección Causas de Infidencia, tomo XXVIII, exp. 2, año 1815, f. 1 vto.

25 ANH, Sección Causas de Infidencia, tomo XXVIII, exp. 2, año 1815 , f. 4 vto.

26 AGN, Sección Causas de Infidencia, t. XXVI, Exp. 2, año 1815, f. 17.

27 «Bando de Policía (1811)». Testimonios de la época emancipadora. Caracas, ANH (Sesquicentenario de la Independencia, $\left.\mathrm{n}^{\circ} 37\right), 1961,472$.

28 «Ordenanzas de Llanos, de la Provincia de Caracas, hechas de orden y por comisión de su sección legislativa del Congreso, por los diputados firmados a su final», 1811, doc. n. 28 , en Materiales para el estudio de la cuestión agraria 1800-1830, vol. I, 82.

29 «Reglamento General de Policía para la Provincia de Venezuela». Boletín del Archivo Nacional, t. XXXI, julio-agosto de $1944, n^{\circ} 123,138$. 
30 AGN, Sección Causas de Infidencia, t. XXVII, exp. 4, año 1815, fs. 99 vto-100.

31 AANH, Sección Civiles-Independencia, t. 353, exp. 1678, año 1816, s/f.

32 «Bando de Policía de 1824», en Durand, Guillermo, Caracas en la mirada propia y ajena. Caracas, Fundarte, 2008, 150.

33 AGN, Sección Civiles, año 1822, t. D, exp. 7, f. 2.

34 AGN, Sección Intendencia de Venezuela, año 1824, t. XVI, f. 54 vto.

35 «Ley de 3 de mayo de 1826. Sobre procedimiento en las causas de hurto y robo». Cuerpo de leyes de la República de Colombia que comprende todas las leyes, decretos y resoluciones dictados por sus congresos desde el de 1821 hasta el último de 1827. Caracas, Imprenta de Valentín Espinal, 1824, 524.

36 AGN, Sección Civiles, t. T, exp. 7, año 1827, f. 3 vto.

37 AGN, Sección Civiles, t. M, exp. 12, año 1824, f. 1 vto.

38 AGN, Sección Causas de Infidencia, t. XXX, exp. 10, f. 13.

39 AGN, Sección Civiles, t. C, exp. 3, año 1825, f. 4.

40 AGN, Sección Civiles, t. C, exp. 7, año 1826, f. 12.

41 Irma Marina Mendoza, «Una rebelión de "hombres de color" en Caracas 1831». http://historiografias.blogspot. com/2010/04/una-rebelion-de-hombres-de-color-en.html

42 AGN, Sección Civiles, t. C, exp. 6, año 1831, f. 34 vto.

43 AGN, Sección Civiles, t. C, exp. 6, año 1831, f. 40 vto.

44 AGN, Sección Civiles, t. A, exp. 11, año 1825, f. 2.

45 AGN, Sección Civiles, t. A, exp. 11, año 1825, f. 1.

46 «Contra el malicioso Aniceto Burgos por palabras subversivas», AGN, Sección Civiles, 1835, f. 9 vto.
47 Reglamento de policía para la Provincia de Caracas, sancionado por la Diputación Provincial en su reunión ordinaria de 1834. Caracas, Impreso por A. Damiron, 1834, 12.

48 «Ley de 23 de Mayo de 1836 señalando el juicio y penas en las causas de hurto». acienpol.msinfo.info/bases/biblo/.../ LEYESYDECRETOS/1/1830_1840_354-359.pdf

49 En los años cuarenta, las cifras en el valle central muestran que el salario habitual oscilaba entre diez y veinte centavos al día, y cuatro pesos mensuales (esto contrasta con los veinte o veinticinco pesos mensuales que ganaban algunos policías rurales). Durante la crisis, era difícil que alguien sugiriera alzar los salarios para incentivar a los trabajadores rurales a mejorar la productividad. Aunque en los años cincuenta se hicieron algunas proposiciones para garantizar a los trabajadores un salario mínimo decente, jamás hubo legislación que las materializara y los jornaleros siguieron siendo los asalariados peor pagados de la sociedad venezolana. (Matthews:23).

50 AGN, Sección Civiles, t. C, exp. 16, 1839, f. 5 vto.

51 AGN, Sección Civiles, t. E, exp. 22, 1841, f. 1.

52 El Liberal, «Editorial». Caracas, 28 de mayo de 1836, $\mathrm{n}^{\circ} 1$.

Liberales y Conservadores. Textos Doctrinales, t. I, 25.

53 Diario de Caracas, Caracas Agosto 27 de 1846. Trim. 2, nro. 117.

54 AGN, Sección Civiles, t. M, exp. 13, año 1845, f. 1.

55 AGN, Sección Civiles, t. M, exp. 13, año 1845, f. 10 vto.

56 Para mayor información, véase: Matthews, Rojas, Carrera Damas (2006).

57 Código de Policía Nacional. Caracas, Imprenta republicana de Eduardo Ortíz, 1854, 13.

\section{Referencias}

\section{Fuentes primarias}

\section{-Archivos}

Archivo de la Academia Nacional de la Historia (AANH)

Sección Civiles-independencia

Sección Civiles

Sección Criminales

Sección Judiciales

Archivo General de la Nación (AGN)

Sección Civiles 
Sección Gobernación y Capitanía General

Sección Intendencia de Ejército y Real Hacienda

Sección Real Hacienda

Sección Secretaría de Interior y Justicias

Sección Reales Cédulas

Sección Reales Provisiones

Sección Reales Órdenes

Sección Archivo de Aragua

Sección Archivo de Barquisimeto

Archivo del Libertador. Disponible en: www.archivodellibertador.gob.ve/escritos/inicio.php

\section{-Hemerografía}

Gaceta de Caracas (1808-1822)

El Patriota de Venezuela (1811)

El Mercurio Venezolano (1811)

El Venezolano (1843)

El Fanal (1830,1831)

El Indicador del Orinoco (1826)

El liberal (1836)

\section{-Obras de referencia}

Diccionario de Autoridades-Tomo V (1737). http://web.frl.es/DA.html

\section{Bibliografía}

AA. VV. (1978). Materiales para el estudio de la cuestión agraria en Venezuela (1800-1830). T. I. Caracas: CDCH/UCV.

Acosta, C. (2006). Lo que debe entenderse por "pueblo». https://omerta.gitbooks.io/cecilio-acosta-obrascompletas-i/content/lo_que_debe_entenderse_por_pueblo.html

Annino, A. y Guerra, F.X. (2003). Inventando la Nación: Iberoamérica siglo XIX. México: Fondo de Cultura Económica.

Buck-Morss, S. (2005). Walter Benjamin, escritor revolucionario. Buenos Aires: Interzona.

Araya Espinoza, A. (1999). Ociosos, vagabundos y malentretenidos en Chile Colonial. Santiago de Chile: LOMCentro de Investigaciones Diego Barros Arana.

Araya Espinoza, A. y Valenzuela Márquez, J. (2010). América Colonial. Denominaciones, clasificaciones e identidades. Santiago de Chile: RIL Editores/Universidad de Chile.

Appun, K.F. (1961). En los trópicos. Caracas: Universidad Central de Venezuela.

Arcila Farías, E. (1946). Economía colonial de Venezuela. México: Fondo de Cultura Económica.

Bache, R. (1982) La República de Colombia en los años 1822-1823: notas de viaje: con el itinerario de la ruta entre Caracas y Bogotá y un apéndice. Caracas: Instituto Nacional de Hipódromos.

Balandier, G. (1993). El desorden. La teoría del caos y las ciencias sociales. Elogio de la fecundidad del movimiento. Barcelona: Gedisa.

Bando de Policía de 1824 (2008). En Durand, G. Caracas en la mirada propia y ajena. Caracas: Fundarte. Bellerman, F. (2007). Diarios Venezolanos (1842-1845). Caracas: Galería de Arte Nacional. 
Baralt, R.M.y Díaz, R. (1975). Resumen de la Historia de Venezuela. T. II. Caracas: Academia Nacional de la Historia.

Benjamin, W. (1939). Sobre algunos temas en Baudelaire. www.philosophia.cl

Benjamin, W. (1989). Tesis de filosofía de la Historia. En Discursos interrumpidos I. Buenos Aires: Taurus.

Benjamin, W. (2010). Obras. Libros IV/vol. 2. Madrid: Abada.

Benjamin, W. (2013). Cuadros de un pensamiento. Buenos Aires: Imago Mundi.

Bernand, C. (2001). Negros esclavos y libres en las ciudades hispanoamericanas. Madrid: Fundación Histórica Tavera.

Bossio, J. (1972). Historia de las pulperías. Buenos Aires: Plus Ultra.

Bouché, L. (1987). La pulpería, mojón civilizador. Buenos Aires: Corregidor.

Carrera Damas, G. (1972). Sobre la zona intermedia. En La dimensión histórica en el presente de América Latina y Venezuela. Tres conferencias. Caracas: FHE-UCV-Escuela de Historia.

Carrera Damas, G. (1983). La crisis de la sociedad colonial venezolana. Caracas: Monte Ávila Editores.

Carrera Damas, G. (2006). Una nación llamada Venezuela. Caracas: Monte Ávila.

Castellanos, R.R. (1988). Historia de la pulpería en Venezuela. Caracas: Editorial Cabildo.

Chartier, R. (1992). El mundo como representación. Estudios sobre historia cultural. Barcelona: Gedisa.

Chartier, R. (1994). «Cultura Popular»: Retorno a un concepto historiográfico. Manuscrits, (12), 43-62.

Código de Policía Nacional (1854). Caracas: Imprenta de Eduardo Ortiz.

Colección Pensamiento Político del siglo XIX. Liberales y Conservadores. Textos Doctrinales, t. I. Caracas: Ediciones de la Presidencia de la República.

Conjuración de 1808 en Caracas para la formación de una Junta Suprema Gubernativa (Publicación n 3). V. I. Caracas, Instituto Panamericano de Geografía e Historia, 1949.

Dauxion Lavaysse, J.J. (1967). Viaje completo a las islas de Trinidad, Tobago, Margarita y a las diversas partes de Venezuela en la América Meridional. Caracas: Instituto de Antropología e Historia (UCV).

De Certeau, M. (1994). La cultura en plural. Buenos Aires: Nueva Visión.

De Certeau, M. (2000a). La invención de lo cotidiano. 1. Artes del hacer. México: Universidad IberoamericanaInstituto Tecnológico y de Estudios Superiores de Occidente.

De Certeau, M. (200ob). La invención de lo cotidiano. 2. Habitar, cocinar. México: Universidad Iberoamericana-Instituto Tecnológico y de Estudios Superiores de Occidente.

Díaz Sánchez, R. (1967). Guzmán. En Obras Selectas. Caracas/Madrid: Edime.

Díaz Sánchez, R. (2003). La virgen no tiene cara. En Cuentos negristas. Caracas: Biblioteca Ayacucho.

Didi-Huberman, G. (2011). Ante el tiempo. Historia del arte y anacronismo de las imágenes. Buenos Aires: Adriana Hidalgo.

Didi-Huberman, G. (2014). Volver sensible/hacer sensible. En Jacques Ranciere et al. ¿Qué es un pueblo? Buenos Aires: Eterna Cadencia, 86-88.

Duane, W. (1968). Viaje a la Gran Colombia en los años 1822-1823. De Caracas y La Guaira a Cartagena, por la Cordillera hasta Bogotá, y de aquí en adelante por el río Magdalena. II tomos. Caracas: Instituto Nacional de Hipódromos.

El primer mercado establecido en la ciudad de Caracas. Boletín del Archivo General de la Nación, t. XVI, $\mathrm{n}^{\circ}$ 210, enero-junio de 1966.

Farge, A. (1991). La atracción del archivo. Valencia: Edicions Alfons El Magnanim.

Farge, A. (1995). Subversive Words. Public opinion in eighteenth-century France. Pennsylvania: Pennsylvania State University Press.

Farge, A. (2008). Efusión y tormento. El relato de los cuerpos. Historia del pueblo en el siglo XVIII. Buenos Aires: Katz. 
Foucault, M. (1992). El orden del discurso. Barcelona: Tusquets.

Foucault, M. (2001). Los anormales: Curso en el Collège de France 1974-1975. México: Fondo de Cultura Económica.

Foucault, M. (2002). Defender la sociedad. México: Fondo de Cultura Económica.

Foucault, M. (2008). Vigilary Castigar. El nacimiento de la prisión. Buenos Aires: Siglo XXI.

Foucault, M. (2007). Los anormales. Buenos Aires: Fondo de Cultura Económica.

Foucault, M. (2010). El cuerpo utópico. Las Heterotopías. Buenos Aires: Nueva Visión.

González Stephan, B. (1995). Modernización y disciplinamiento. La formación del ciudadano del espacio público y privado. En Esplendores y miserias del siglo xix. Cultura y sociedad en América Latina. Caracas: Universidad Simón Bolívar.

González Stephan, B. (2006). La construcción espectacular de la memoria nacional: cultura visual y prácticas historiográficas (Venezuela siglo XIX). VII Jornadas Andinas de Literatura Latinoamericana. Bogotá.

González Stephan, B. (2011). Fijar la patria. Eduardo Blanco y el imaginario venezolano. Caracas: Bid \& co. Editor.

Hall, S. (1984). Notas sobre la deconstrucción de lo popular. En Samuel, R. (Ed.). Historia populary teoría socialista. Barcelona: Crítica. file://C:/Users/neller\%20ochoa/Desktop/notas\%2osobre\%20la\%20 deconstruccion\%2ode\%2olo\%2opopular.pdf

Hankshaw, J. (1975). Reminiscencias de Sudamérica. Dos años y medio de residencia en Venezuela. Caracas: Ediciones de la Presidencia de la República.

Humboldt, A. (1991). Viaje a las regiones equinocciales del Nuevo Continente. T. III. Caracas: Monte Ávila Latinoamericana.

Izard, M. (2009). El miedo a la Revolución. Caracas: Centro Nacional de Historia.

Izard, M. (2011). Ni cuatreros ni montoneros, llaneros. Caracas: Centro Nacional de Historia.

Ker Porter, Sir R. (1997). Diario de un diplomático británico en Venezuela, 1825-1842. Caracas: Fundación Polar.

Kinsbruner, J. (1987). Petty Capitalism in Spanish America. The Pulperos of Puebla, Mexico City, Caracas, and Buenos Aires. Colorado: Westview Press.

Koselleck, R. (2007). Crítica y crisis. Un estudio sobre la patogénesis del mundo burgués. Madrid: Trotta.

Leal Curiel, C. (1990). El Discurso de la fidelidad. Caracas: Academia Nacional de la Historia.

Ludmer, J. (1995). Héroes hispanoamericanos de la violencia popular: construcción y trayectorias. (Para una historia de los criminales populares en América Latina). AIH. Actas XII (1995). cvc.cervantes.es/literatura/ aih/pdf/12/aih_12_7_005.pdf

Ludmer, J. (2000). El género gauchesco. Un tratado sobre la patria. Buenos Aires: Perfil.

Martí, M. (1998). Documentos relativos a su visita pastoral de la Diócesis de Caracas, 1771-1784. T. II. Caracas: Academia Nacional de la Historia.

Matthews, R.P. (1977). Violencia rural en Venezuela, 1840-1858: antecedentes socio-económicos de la guerra federal. Caracas: Monte Ávila Editores.

Mayo, C. (2000a). Pulperos y pulperías en Buenos Aires. Buenos Aires: Biblos.

Mayo, C. (200ob). Vivir en la frontera. La casa, la dieta, la pulpería, la escuela (1770-1870). Buenos Aires: Editorial Biblos.

Ochoa, N. (2015). Despojos inconformes. Saqueos y secuestro de bienes en la Provincia de Caracas 1810-1821. Caracas: Centro Nacional de Historia.

Ochoa, N. y Flores, J. (2013). Se acata pero no se cumple. Historia y sociedad en la Provincia de Caracas (siglo XVIII). Caracas: Centro Nacional de Historia.

Parolo, M.P. (2004). Las pulperías en Tucumán en la primera mitad del siglo XIX. Un espacio de libertad y de conflicto. Travesía, (7/8), 127-148. 
Pellicer, L.F. (2005). Entre el honory la pasión. Facultad de Humanidades y Educación UCV, Caracas.

Pellicer, L.F. y otros (2011). Diccionario Memorias de la Insurgencia. Caracas: Centro Nacional de Historia.

Pérez, F.J. (2012). Diccionario histórico del español en Venezuela. Caracas: Fundación Polar.

Pérez Vila, M. (1997). Club de los sin camisa. En Diccionario de Historia de Venezuela. T. I. Caracas: Fundación Polar.

Picón Salas, M. (1951). Perfil de Caracas. Crónica de Caracas. Agosto-Diciembre de 1951, II(8).

Pino Iturrieta, E. (2006). Fueros, civilización y ciudadanía. Estudios sobre el siglo XIX en Venezuela. Caracas: UCAB.

Progreso material de Caracas a mediados del siglo XVIII (1956). Boletín del Archivo General de la Nación, n 173.

Quintero, I. (2002). La conjura de los mantuanos. Caracas: UCAB.

Rama, Á. (1998). La ciudad letrada. Montevideo: Arca.

Ramos, J. (1993). La ley es otra: Literatura y constitución del sujeto jurídico María Antonia Mandinga en el Archivo de la Ley. En Esplendores y miseria del siglo XIX. Cultura y sociedad en América Latina. Caracas: Universidad Simón Bolívar/Monte Ávila Editores.

Ramos, J. (2009). Desencuentros de la modernidad en América Latina. Literatura y política en el siglo XIX. Caracas: Fundación El Perro y la Rana.

Rancière, J. (2010). El espectador emancipado. Buenos Aires: Manantial.

Rancière, J. (2014). El inhallable populismo. En Rancière, J. y otros. ¿Qué es un pueblo? Buenos Aires: Eterna Cadencia.

Rey, J.C. (2007). El pensamiento político en España y sus provincias americanas durante el despotismo ilustrado (1759-1808). En Gual y España y la independencia frustrada. Caracas: Fundación Polar, 43-162.

Rojas, A. (2009). Insumisión popular 1830-1848. Caracas: Centro Nacional de Historia.

Romero, J.L. (2010). Latinoamérica: las ciudades y las ideas. Buenos Aires: Siglo XXI.

Scott, J. (2004). Los dominados y el arte de la resistencia. México: Era.

Semple, R. (1812). Bosquejo del estado actual de Caracas, incluyendo un viaje por La Victoria y Valencia hasta Puerto Cabello. En Tres testigos europeos de la Primera República 1808-1814. Caracas: Ediciones de la Presidencia de la República, 1974, 1-89.

Serrano Páez, E. (2007). Venezuela 1810-1850: pueblos y pueblos, dos formas de construir la nación. Anuario de Estudios Bolivarianos, (14), 163-186.

Solórzano, K. (1998). Se hizo seña. Medición y percepción del tiempo en el siglo XVIII caraqueño. Caracas: Editorial Planeta Venezolana.

Solórzano Pereira, J. de. (1648). Política Indiana. Madrid: Diego Díaz de la Carrera.

Testimonios de la época emancipadora (1961). Caracas: Academia Nacional de la Historia.

Textos oficiales de la Primera República de Venezuela (1983). T. I. Caracas, Academia Nacional de la Historia.

Thompson, E.P. (1984). Tradición, revuelta y consciencia de clase. Barcelona: Crítica.

Thompson, E.P. (2012). La formación de la clase obrera en Inglaterra. Madrid: Capital Swing Libros.

Uslar Pietri, A. (1961). Estudio Preliminar. En Testimonios de la época emancipadora. Caracas: Academia Nacional de la Historia.

Uslar Pietri, A. (1988). Las lanzas coloradas y cuentos selectos. Caracas: Biblioteca Ayacucho.

Uslar Pietri, A. (2008). Medio milenio de Venezuela. Caracas: El Nacional.

Vallenilla Lanz, L. (1991). Cesarismo Democrático y otros textos. Caracas: Biblioteca Ayacucho. 